УДК 316.4

DOI: $10.18101 / 1994-0866-2019-2-36-42$

\title{
МЕЖЭТНИЧЕСКОЕ СОГЛАСИЕ В РЕСПУБЛИКЕ БУРЯТИЯ. ПОСТСОВЕТСКИЙ ПЕРИОД
}

\author{
(C) Чимитова Ирина Зоригтоевна \\ кандидат социологических наук, старший преподаватель, \\ Бурятская государственная сельскохозяйственная академия им. В. Р. Филиппова \\ Россия, 670024, г. Улан-Удэ, ул. Пушкина, 8 \\ E-mail: rindaol@mail.ru
}

На территории Бурятии в течение столетий взаимодействия этносов-старожилов региона, прежде всего бурят и русских, сформировались и укрепились такие качества, как сотрудничество, спокойствие, стабильность, добрососедство, дружба, что позволяет при оценке межэтнических отношений в этом субъекте РФ использовать понятие «межэтническое согласие». Отмечая роль природно-географических условий, а также направленности государственной политики центра по отношению к окраинам, автор рассматривает внешние факторы и типичные проявления согласия указанных этносов в 90-е годы прошлого столетия и в современных условиях. Нынешняя стабильность межэтнических отношений в Республике Бурятия является, в частности, следствием позитивного тренда межэтнического взаимодействия в прошлом. В качестве факторов и проявлений межэтнического согласия этносов-старожилов анализируются черты их характера, межконфессиональная толерантность, распространенность национально-смешанных семей. Результатом многовековых процессов взаимной адаптации, консолидации и интеграции является межэтническое согласие.

Ключевые слова: этнос; этнос-старожил; межэтническое согласие; Россия; Бурятия; буряты; русские; добрососедство; дружба; сотрудничество; характер народа; межконфессиональная толерантность; национально-смешанная семья.

Для цитирования:

Чимитова И. 3. Межэтническое согласие в Республике Бурятия. Постсоветский период // Вестник Бурятского государственного университета. Философия. 2019. Вып. 2. C. $36-42$.

Интенсификация контактов между представителями разных народов и культур в современном глобализирующемся мире определяет актуальность проблемы межэтнического взаимодействия. В традиционно многонациональной России сложились сходство, а порой и общность образа жизни и менталитета представителей разных этносов, т. к. «постоянно шел процесс взаимного привыкания, взаимного проникновения, смешивания народов на семейном, дружеском, служебном уровне» [1, с. 1].

Закономерным результатом в течение столетий этих процессов в Бурятии являются такие качества межэтнического взаимодействия в постсоветский период этносов-старожилов региона, прежде всего наиболее крупных по численности бурят и русских, составляющих в совокупности большинство населения и по этой причине называемых основными народами региона, как сотрудничество, добрососедство, стабильность, спокойствие, дружба, что позволяет по праву обозначать их термином «согласие», т. к. перечисленные характеристики являются атрибутами последнего. 
Стабильность межэтнических отношений в Республике Бурятия в 1990-е годы и первые десятилетия XXI в. является, в частности, следствием позитивного характера межэтнического взаимодействия в прошлом. Такие отношения в силу их долговременности стали традицией, которую не смогли переломить неоднократные коренные перемены основ жизнеустройства, смена системы ценностей и идеологии, пережитые страной.

Вкратце остановимся на некоторых трактовках содержания понятия «согласие». Прежде всего большинство исследователей указывают на такое качество согласия, как психологическая готовность субъектов коммуникации к контакту. Например, В. И. Самохвалова отмечает наличие у них внутренней установки «на готовность принять другого, признать наличие у него собственных интересов, способность открыться для диалога» [2, с. 31-32]. Благодаря такой установке взаимодействующие стороны, в том числе этносы, их группы и отдельные представители, сотрудничают друг с другом и поддерживают добрососедские отношения.

Л. М. Дробижева приводит такие маркеры согласия, как «ценность диалогового урегулирования противоречивых ситуаций, межличностное и межгрупповое доверие, согласованные ценностные ориентации, общее видение образа мира. Все это проявляется в способности людей жить в сложном, многообразном мире, взаимодействовать друг с другом на принципах доверия, равенства и справедливости» [3, с. 81].

Действительно, без общности представлений, в том числе образа мира, основных целей, согласованных ценностных ориентаций, совместная деятельность в некоторых самых необходимых пределах и соответствующий уровень диалога возможны, однако доверие и справедливость, указанные Л. М. Дробижевой, а также добрососедство, дружба и другие элементы, которые мы считаем проявлениями согласия между субъектами коммуникации, более проблематичны и зависят от конкретных условий.

Что касается равенства, то этот вопрос требует специального рассмотрения, но полагаем, что в данном случае более адекватным является понятие «равноправие».

Перечисленные составляющие согласия характеризуют отношения между этносами-старожилами Бурятии. Не случайно понятие «согласие» нередко применяется при оценке межэтнических отношений в этом субъекте РФ [4, с. 29-34; 5, c. $64-70]$.

В связи с тем, что рассмотреть все причины и факторы, определившие межэтническое согласие народов-старожилов Бурятии, в статье не представляется возможным, ограничимся лишь перечислением некоторых из них, а также анализом наиболее типичных проявлений согласия указанных этносов в 90-е гг. прошлого столетия и в начале $2000-$ х гг.

Прежде всего нельзя недооценивать значения таких объективных детерминант межэтнического взаимодействия, как природно-географические условия и тесно связанные с ними демографические процессы. Естественно полагать, что одним из стимулов к сближению и установлению сотрудничества, а затем его развитию со стороны относительно малочисленных общностей различного этнического происхождения была необходимость выжить на обширной, в основном почти неосвоенной территории с суровым климатом. 
Важным детерминирующим фактором была и государственная политика относительно обустройства окраин Российской империи, игравшая роль внешнего фактора межэтнической коммуникации и на территории Бурятии. Основным ее направлением была лояльность центра к этническому своеобразию периферии. Как отмечает Г. Абдулкаримов, эта политика была направлена на сохранение, с некоторыми изменениями, на периферии исторически сложившихся этнокультурных комплексов, на предоставление ей «относительной автономии в реализации этнокультурных интенций» [6, с. 277, 274].

В качестве важнейших внутренних факторов межэтнического согласия в течение длительного времени выступали (и сохраняются в качестве таковых в настоящее время), в частности, особенности, присущие контактирующим этносам и региону их проживания. Остановимся на них подробнее.

Существенная роль в формировании и поддержании оптимального уровня взаимопонимания между этносами принадлежит определенным чертам их характера. Среди таковых применительно к бурятскому характеру различные авторы, в том числе декабристы, в разное время называли такие его качества, способствующие установлению отношений согласия, как миролюбие, склонность к компромиссу в ситуации конфликта, восприимчивость к достижениям других народов, гостеприимство, доброжелательное отношение к другим народам и др.

Национальный характер русского народа изучался глубоко и во многих аспектах, в том числе корифеями отечественной философии. Н. А. Бердяев писал, что русский народ есть не чисто европейский и не чисто азиатский, отмечал, в частности, необъятность его души, подчеркивал моральный характер русской литературы, интерпретировал идею братства людей и народов как русскую идею $[7$, c. $78,90,144]$. Давнюю связь русской культуры с культурами соседних народов и терпимость к ним, стремление русской литературы к социальной справедливости исследовал Д. С. Лихачев [8, с. 3, 4].

Хорошо известно, какую колоссальную помощь оказали представители наиболее развитых народов, прежде всего русского, в становлении многих этносов европейской и азиатской частей страны, особенно в эпоху Советского Союза, в качестве субъектов экономической, политической, культурной деятельности на уровне достижений XX в., в успешной модернизации всех сторон их бытия и сознания.

В конце 1980-х - начале 1990-х гг. в СССР, в том числе и Бурятии, наблюдается резкая активизация политических процессов, в том числе и в области этнических отношений. В Бурятии появились этнополитические организации, позиционировавшие себя защитниками интересов титульного народа, лидеры которых, опираясь на идейное наследие конца XIX - начала XX в., сформулировали ряд положений, позже получивших в литературе название «бурятский национализм».

Суть его заключается в следующем: бурят объединяет с монголами общее великое прошлое, надо укреплять связи с ними и другими народами, близкими по происхождению; необходимо реабилитировать ущемленные в прошлом права титульного этноса, восстановить территорию республики в границах 1937 г., вернуть в отредактированном виде (Бурят-Монголия) ее прежнее название; обеспечить прежде всего через механизм выборов особый политический статус бурятского народа; надо выводить из кризиса бурятский язык и культуру. 
Если социокультурные аспекты этих идейных конструктов находили всеобщее понимание, то политические не вызвали сколько-нибудь массового отклика. «Этнический ренессанс» и связанные с ним события конца 1980-х и последнего десятилетия прошлого века не повлияли на состояние межэтнических отношений в Республике Бурятия, т. к. спорадические проявления русского национализма не носили ярко выраженного характера, а бурятский национализм, хотя и производил более заметное впечатление, но остался в памяти как кратковременный всплеск, затронувший лишь незначительную часть потенциальной аудитории лидеров этнополитических организаций.

Оценку этому явлению дает А. А. Елаев: «Общественная мысль идеологов бурятского возрождения была обращена преимущественно в прошлое. Осмысление будущего - редкое исключение. В этом кроется одна из причин отсутствия в начавшемся процессе возрождения перспективных идей этнического развития бурятского народа» [9, с. 309].

Другая причина недолговечности большинства указанных идеологем состоит, по нашему мнению, в их узкой этнической ориентированности, недостаточном учете того факта, что в Бурятии межэтническое согласие является непреложной данностью, реальностью, частью образа жизни и менталитета населения, многовековой традицией.

Согласие между этносами-старожилами региона как массовое явление формировалось издавна. В процессе совместной жизнедеятельности на одной территории при любых политических режимах они взаимно адаптировались, учились друг у друга, сотрудничали. Происходили взаимное познание, обогащение, региональная консолидация и интеграция, а также адекватная оценка друг друга.

В связи с вышесказанным необходимо отметить, что при всей значимости сведений о бурятском характере, имеющихся в бурятоведческой научной литературе, большинство из них связано с изучением внутриэтнических коммуникаций. Это, например, такие черты, как почитание неба, очага, весомость семейных ценностей, почитание старших и т. д. Что же касается качеств, проявляющихся преимущественно в межэтнических контактах, то убедительным их постижением является художественная литература, в частности, публицистика современных писателей Бурятии.

Как известно, художник, в том числе писатель, подчас выступает по сравнению с ученым первопроходцем. Помимо воплощения в конкретной, наглядной, т. е. предметной форме, образы, создаваемые художниками слова, иногда содержат нечто еще неуловимое и непостижимое для рационального познания, но ощущаемое автором интуитивно, на уровне предвосхищения, догадки, озарения и т. д.

Так, представляют интерес с точки зрения точности наблюдений и четкости выводов ряд утверждений современного бурятского писателя Г. Башкуева, который пишет, что за время совместного проживания «русские жители республики научились уважать не только чисто человеческие качества кочевников, но и их способность быстро учиться и порой превосходить учителей. Офицеры Забайкальского военного округа (вслед за атаманом Семеновым) предпочитали расторопных солдат-бурят, особенно в частях, где много техники. Капитаны подводных лодок Тихоокеанского флота, изучая списки новобранцев, в графе «нацио- 
нальность» привычно искали и ищут бурят - из поколения в поколение... [10, c. 80$]$.

Г. Башкуев также справедливо отмечает, что качества характера русского населения Бурятии (как части русского суперэтноса. - прим. И. Ч.) снискали уважение со стороны бурят, оценивших их «великодушие, хозяйскую сметку, деловую хватку и трудолюбие... Не раз я слышал, как буряты говорили в присутствии детей и им в назидание, что «русские - хорошие люди, с русскими надо хорошо жить» $[10$, с. 80$]$.

У поколений местных русских за столетия проживания в Восточной Сибири в результате межэтнического взаимодействия сформировались и некоторые специфические качества характера. Анализируя жизнь республики в 1990-е годы, писатель подводит итог многолетних наблюдений: «Русское население Забайкалья ... принципиально отличалось от россиян по ту сторону Уральского хребта. По тому как тебя приветствуют, слушают, даже произносят дежурные фразы, не говоря уже о готовности обсуждать тот или иной вопрос... Тысячи мелочей могут свидетельствовать о том, что тебя принимают за равного партнера: в беседе и в деле» $[10$, с. 80$]$.

Межэтническое взаимодействие в Бурятии в 2000-е годы по-прежнему остается отношениями согласия. Это подтверждают итоги социологических исследований. В ходе одного из опросов, проведенного в 2011 г., эксперты назвали межэтнические отношения в Бурятии «спокойными, ровными»; писали, что «у нас очень большой задел прочности в области межнациональной стабильности», «я не видел межнациональную рознь между русскими и бурятами, потому что все время живем вместе» [11, с. 58].

К числу региональных факторов межэтнического согласия и вместе с тем одним из его проявлений на протяжении столетий относится свойственное Бурятии сосуществование шаманизма, буддизма и православия, которое, несмотря на конкуренцию между ними, в основном было мирным и таковым остается поныне. Наряду с приверженностью к шаманизму и буддизму буряты исповедовали и православие. Элементы религиозных практик аборигенов Восточной Сибири наблюдались и имеют место в наши дни в жизнедеятельности русского населения. Нередким явлением было сочетание в ментальности и религиозной обрядности верующего одновременно элементов двух-трех вер, которое встречается и ныне. Это свидетельствует о том, что в конкретных условиях региона перечисленные конфессии проявляли гибкость, способность адаптироваться к ситуации, результативно взаимодействовать друг с другом и паствой.

Важным фактором и одновременно проявлением межэтнического согласия основных этносов Бурятии является распространенность национальносмешанных семей, характерная и для предшествующих периодов. «Смешанные браки, завязывавшие узы родственных отношений между русскими и бурятскими семьями, вели зачастую к основанию прочной дружбы между ними», — пишет о ситуации XVIII в. О. В. Бураева [12, с. 113]. Следствием долговременного межэтнического смешения населения стало наличие у многих старожилов близких с представителями народа-соседа родственников. Согласно данным социологического опроса населения республики 2005 г., на вопрос «Есть ли среди ваших родственников представители другой национальности?» 49,9\% респондентов выбра- 
ли вариант «Да» [13, с. 29], что свидетельствует о высокой степени близости и доверия представителей разных этнических групп.

Таким образом, взаимодействие между этносами-старожилами Бурятии в постсоветский период осуществляется на основе согласия. Наряду с внешними детерминантами существенную роль в этом сыграли такие внутренние факторы межэтнического согласия, как черты характера контактирующих народов, межконфессиональная толерантность, распространенность национально-смешанных семей, а также долговременность позитивного и многопланового межэтнического взаимодействия, ставшая традицией. «Этнический ренессанс» конца 1980-х и последнего десятилетия прошлого века, сопровождавшийся кратковременным всплеском национализма, не повлияли на стабильность межэтнического взаимодействия в республике, которое и в настоящее время является территорией межэтнического согласия.

Сохранение согласия народов важно для нынешних и новых поколений жителей как Бурятии, так и Российской Федерации в целом как крупнейшего полиэтнического государства.

Лuтература

1. Путин В. В. Россия: национальный вопрос // Независимая газета. 2012. 25 янв. С. 1, 3-4.

2. Самохвалова В. И. Идентичность, норма и пределы толерантности // Философские науки. 2008. № 4. С. 26-45.

3. Дробижева Л. М. Потенциал межнационального согласия: осмысление понятия и социальная практика в Москве // Социс. 2015. № 11. С. 80-90.

4. Вопросы сохранения и развития толерантности, проблемы гражданской активности населения Республики Бурятия / Д. Ц. Будаева [и др.]. Улан-Удэ: Изд-во Бурят. гос. ун-та, 2010. $140 \mathrm{c}$.

5. Чимитова И. 3. Межэтническая толерантность: сущность, характер и особенности проявления в Республике Бурятия. Улан-Удэ: Изд-во БГСХА им. В. Р. Филиппова, 2011. $138 \mathrm{c}$.

6. Абдулкаримов Г. Теоретические проблемы актуальной этнополитики в России: этносоциология модернизации современной России. М.: Весь Мир, 2008. 336 с.

7. Бердяев Н. А. Русская идея// Вопросы философии.1990. № 1. С. 77-144.

8. Лихачев Д. С. О национальном характере русских // Вопросы философии. 1990. № 4. C. 3-6.

9. Елаев А. А. Бурятский народ: становление, развитие, самоопределение. М.: Вестком, 2000. $352 \mathrm{c}$.

10. Башкуев Г. Т. На переломе. Публицистика. Проза. Пьесы. Улан-Удэ: Республиканская типография, 2007. 492 с.: ил.

11. Межнациональные, религиозные, этнопсихологические реалии Бурятии и вопросы гражданской активности населения / отв. ред. Ц. Б. Будаева. Улан-Удэ: Изд-во Бурят. гос. ун-та, 2013. 168 с.

12. История Бурятии: в 3 т. Т. 2. XVII - начало XX в. / Л. Л. Абаева [и др.]. УланУдэ: Изд-во БНЦ СО РАН, 2011. 624 с.

13. Межнациональные и этнические вопросы Бурятии / сост. Ц. Б. Будаева. Улан-Удэ: Изд-во ВСГУТУ, 2006. 132 с. 


\section{ETHNIC CONSENT IN THE POST-SOVIET REPUBLIC OF BURYATIA}

Irina Z. Chimitova

Cand. Sci. (Sociol.), Senior Lecturer,

Filippov Buryat State Agricultural Academy

8 Pushkina St., Ulan-Ude 670024, Russia

E-mail: rindaol@mail.ru

Over the centuries of the interaction of old ethnoses, firstly, the Buryats and Russians, on the territory of the Republic of Buryatia such human qualities as cooperation, calm, stability, good-neighborliness, friendliness had been developed and strengthened. This allows us to use the concept "ethnic consent" when assessing inter-ethnic relations in the republic. Noting the role of natural and geographical conditions, as well as the state policy of the center in relation to rimland, we consider external factors and typical manifestations of the ethnic consent in the 1990s and modern conditions. The current stability of inter-ethnic relations in the Republic of Buryatia is, in particular, a consequence of the positive trend in this sphere in the past. We have analyzed factors and manifestations of the ethnic consent of old ethnoses, such as their character traits, interfaith tolerance, and the prevalence of national mixed families. The ethnic consent in the republic is a result of centuries-long processes of mutual adaptation, consolidation and integration.

Keywords: ethnos; old ethnoses; ethnic consent; Russia; Buryatia; Buryats; Russians; good-neighborliness; friendship, cooperation; character of the people; interreligious tolerance; national mixed family. 